University of Nebraska - Lincoln

DigitalCommons@University of Nebraska - Lincoln

Agronomy \& Horticulture -- Faculty Publications

Agronomy and Horticulture Department

1956

\title{
Effects of Irradiation, Maleic Hydrazide, Temperature, and Age on Enzyme Activity in Seedlings of Corn (Zea mays L.)
}

Francis A. Haskins

University of Nebraska-Lincoln, fhaskins@neb.rr.com

Harold Chapman

University of Nebraska, Lincoln, Nebraska

Follow this and additional works at: https://digitalcommons.unl.edu/agronomyfacpub

Part of the Plant Sciences Commons

Haskins, Francis A. and Chapman, Harold, "Effects of Irradiation, Maleic Hydrazide, Temperature, and Age on Enzyme Activity in Seedlings of Corn (Zea mays L.)" (1956). Agronomy \& Horticulture -- Faculty Publications. 162.

https://digitalcommons.unl.edu/agronomyfacpub/162

This Article is brought to you for free and open access by the Agronomy and Horticulture Department at DigitalCommons@University of Nebraska - Lincoln. It has been accepted for inclusion in Agronomy \& Horticulture -Faculty Publications by an authorized administrator of DigitalCommons@University of Nebraska - Lincoln. 


\title{
Effects of Irradiation, Maleic Hydrazide, Temperature, and Age on Enzyme Activity in Seedlings of Corn (Zea mays L.)
}

\author{
By \\ Francis A. Haskins and Harold W. Chapman \\ Departments of Agronomy and Horticulture, \\ University of Nebraska, Lincoln, Nebraska \\ (Received March 22, 1956)
}

The work of Schmidt and Frolik (1951) and of Beard (1955) has shown that plants of corn (Zea mays L.) grown from seeds treated with appropriate doses of X-rays or thermal neutrons are greatly reduced in stature and survival in comparison with control plants, and that pronounced increases in chromosomal abnormalities and pollen sterility also result from seed irradiation. It is reasonable to suspect that these morphological and cytological effects might be associated with changes in the metabolism of the plant. Accordingly, a series of experiments has been conducted in which preparations of normal corn seedlings and preparations of dwarfed seedlings grown from irradiated seeds have been compared with respect to several enzyme activities. Measurements have also been made using seedlings which were stunted by the effects of seed treatment with maleic hydrazide, and other seedlings which were stunted by subjection to lowered temperature during growth.

The enzyme activities which have been studied are catalase, cytochrome oxidase, peroxidase, acid phosphatase, and polyphenolase. The influence of different types of radiation on various enzyme activities, including some of those listed above, in certain mammals and microorganisms has been the object of rather extensive studies (e.g. Patt, 1954, and Powell and Pollard, 1955). Obviously, however, irradiating a dormant seed, planting the seed, physiol. Plant., 9, 1956

$[356]$ 
and using the resulting seedling for enzyme assays is quite different from irradiating a rat or mouse, removing certain tissues or organs, and using these in enzyme studies, or irradiating a population of bacterial cells and immediately using these cells in making an enzyme preparation. Although Mikaelsen and Halvorsen (1953) observed a decrease in the rate of respiration of germinating barley seeds resulting from treatment of the dormant seeds with X-rays, their report does not include information regarding specific enzyme activities. There is very little information available concerning the influence of seed treatment on the enzymatic properties of seedlings grown from the treated seeds.

\section{Materials and Methods}

The corn hybrid, L $289 \times 1205$, was used in these investigations. Seedlings were grown in vermiculite which was saturated with nutrient solution (solution 1 of Hoagland and Arnon, 1950, supplemented with trace minerals) immediately after planting and was kept moist with tap water for the remainder of the growing period. All seedlings except those in the temperature study were grown in the laboratory at room temperature, which varied between $22^{\circ}$ and $35^{\circ} \mathrm{C}$ during the course of these experiments, under Ken-rad Cool White Standard fluorescent tubes. Light intensity at the level of the seedlings was approximately 1000 foot candles. A 14-hour photoperiod was used.

Seedlings to be used in enzyme preparations were excised at the surface of the vermiculite and the remains of the coleoptiles adhering to the stems were removed and discarded. The term green seedling, as used in this report, therefore refers to only that portion of the seedling above the coleoptilar node.

Seed irradiation. Seeds were sent to the Brookhaven National Laboratory for irradiation. We are indebted to Dr. Seymour Shapiro for conducting the irradiations. For the $X$-ray treatments, seeds were exposed in a single layer $27 \mathrm{~cm}$ from the $\mathrm{X}$-ray source. The X-ray facility was operated at $250 \mathrm{KVP}$ and $30 \mathrm{ma}$, and the X-rays were filtered through $1 \mathrm{~mm}$ of aluminum. The intensity of irradiation at the surface of the seeds was approximately $900 \mathrm{r} / \mathrm{min}$.

Thermal neutron treatments were administered in the thermal column of the nuclear reactor at Brookhaven. Dosage determinations were based on the radioactivity induced in gold foils included with the seeds during treatment. The flux was such that an exposure of 12 hours was required for the highest neutron dosage. The cadmium ratio in the thermal column was approximately $5000: 1$ and the gamma ray contamination approximately $50 \mathrm{r} /$ hour.

Seeds were packaged in moisture-proof containers for mailing to and from Brookhaven, and following their return the seeds were stored in a desiccator over $\mathrm{CaCl}_{2}$ until they were planted.

Maleic hydrazide treatments. Seeds were soaked at room temperature for 24 hours in solutions of the diethanolamine salt of maleic hydrazide (MH 30, U.S. Rubber Company) of various concentrations, then rinsed thoroughly with distilled water and planted in vermiculite.

Temperature treatments. Seedlings were started at room temperature and after 
attaining a height of approximately $60 \mathrm{~mm}$, they were moved to illuminated constant temperature chambers. Temperature control in these chambers was within limits of $\pm 0.5^{\circ}$ C. Fluorescent tubes were used for illumination. The light intensity was similar to that which was used for the other seedlings, and a 14-hour photoperiod was used.

Enzyme assays. The methods which were used in making enzyme preparations and assaying for activities of catalase, cytochrome oxidase, peroxidase, phosphatase, and polyphenolase as well as content of protein nitrogen have been described earlier (Haskins, 1955). All determinations were made in duplicate. Differences between duplicate determinations seldom exceeded 5 per cent in peroxidase, polyphenolase, and phosphatase assays. In cytochrome oxidase and catalase assays, however, duplicate determinations occasionally differed by as much as 20 per cent, particularly when preparations of very low activity were involved.

\section{Results and Discussion}

The data presented in table 1 show that seed treatment with $\mathrm{X}$-rays, thermal neutrons, or maleic hydrazide resulted in a reduction of seedling stature. Similarly, small seedlings were obtained from non-treated seeds by lowering the temperature during growth or by shortening the growth period. In appearance, however, seedlings from treated seeds had extensive leaf mottling and were generally much less vigorous than seedlings which were small because of lowered temperature or reduced growing period. The latter seedlings were essentially free of mottling. Metabolic differences among the small seedlings are indicated by the fact that the seedlings most drastically reduced in stature as a result of seed irradiation or maleic hydrazide treatment yielded preparations appreciably lower in protein nitrogen than preparations of seedlings of comparable stature from the age and temperature series.

Moreover, the seedlings which were small because of the effects of age or temperature differed enzymatically from those which were small by virtue of the effects of seed treatment with $\mathrm{X}$-rays, thermal neutrons, or maleic hydrazide. The height reductions which resulted from the irradiation and maleic hydrazide treatments were found to be associated with appreciable increases in the specific activities of peroxidase, acid phosphatase, and polyphenolase; while the height reductions resulting from the age and temperature treatments were usually accompanied by slight decreases in these three types of enzyme activity (figures $1,2,3$ ). With respect to catalase and cytochrome oxidase, on the other hand, increased enzyme activity and reduced seedling height appeared to be associated for all treatments (figures $4,5)$.

Although seed treatment with X-rays, thermal neutrons, or maleic hydra- 
Table 1. Ages, heights, and fresh weights of green seedlings of L289X1205 corn, and protein nitrogen contents of enzyme preparations from these seedlings.

\begin{tabular}{|c|c|c|c|c|}
\hline Source of material & $\begin{array}{c}\text { Age } \\
\text { (days) }\end{array}$ & $\begin{array}{l}\text { Seedling } \\
\text { height } \\
(\mathrm{mm})\end{array}$ & $\begin{array}{c}\text { Fresh } \\
\text { weight } \\
\text { (gm) }\end{array}$ & $\begin{array}{l}\text { Protein } \mathrm{N} \text { per } \\
\text { ml preparation } \\
\text { (mg) }\end{array}$ \\
\hline Age series $\ldots \ldots \ldots \ldots$ & $\begin{array}{r}11 \\
9 \\
7 \\
5\end{array}$ & $\begin{array}{r}265 \\
213 \\
131 \\
39\end{array}$ & $\begin{array}{l}1.15 \\
0.90 \\
0.57 \\
0.08\end{array}$ & $\begin{array}{l}0.23 \\
0.26 \\
0.30 \\
0.38\end{array}$ \\
\hline 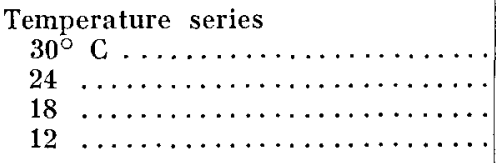 & $\begin{array}{l}9 \\
9 \\
9 \\
9\end{array}$ & $\begin{array}{r}295 \\
214 \\
125 \\
93\end{array}$ & $\begin{array}{l}1.32 \\
0.86 \\
0.54 \\
0.42\end{array}$ & $\begin{array}{l}0.19 \\
0.22 \\
0.28 \\
0.30\end{array}$ \\
\hline 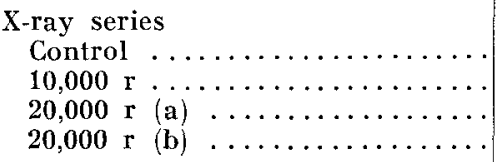 & $\begin{array}{l}9 \\
9 \\
9 \\
9\end{array}$ & $\begin{array}{r}266 \\
256 \\
181 \\
91\end{array}$ & $\begin{array}{l}1.58 \\
1.26 \\
0.93 \\
0.38\end{array}$ & $\begin{array}{l}0.23 \\
0.24 \\
0.24 \\
0.23\end{array}$ \\
\hline 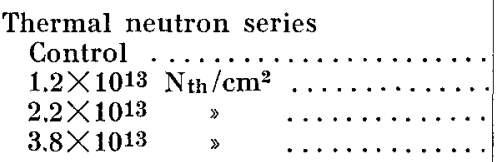 & $\begin{array}{l}8 \\
8 \\
8 \\
8\end{array}$ & $\begin{array}{r}270 \\
204 \\
113 \\
56\end{array}$ & $\begin{array}{l}1.09 \\
0.84 \\
0.44 \\
0.22\end{array}$ & $\begin{array}{l}0.24 \\
0.27 \\
0.29 \\
0.30\end{array}$ \\
\hline 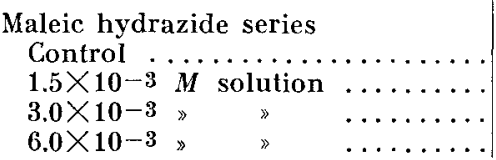 & $\begin{array}{l}8 \\
8 \\
8 \\
8\end{array}$ & $\begin{array}{r}271 \\
171 \\
74 \\
38\end{array}$ & $\begin{array}{l}1.29 \\
0.72 \\
0.23 \\
0.07\end{array}$ & $\begin{array}{l}0.23 \\
0.18 \\
0.21 \\
0.19\end{array}$ \\
\hline
\end{tabular}

zide resulted in altered enzymatic activities in the green seedlings, it is improbable that these treatments exerted a direct influence on the enzymes studied in these experiments. This conclusion is based on measurements (unpublished results from this laboratory) of the five types of enzyme activity in preparations of embryos from control, X-ray-treated, and thermal neutrontreated seeds, and of etiolated shoots from control seeds and seeds treated with X-rays, thermal neutrons, or maleic hydrazide. These assays, in contrast to those employing green seedlings, failed to show large or consistent differences with respect to any of the enzyme activities studied. Thus it appears that the irradiation and maleic hydrazide treatments of corn seeds bring about primary changes of an unknown nature, and that among the manifestations of these unknown changes are altered patterns of polyphenolase, peroxidase, and phosphatase activity in the green seedling. Although the data indicate certain similarities in the effects of $\mathrm{X}$-rays, thermal neutrons, and maleic hydrazide, the primary metabolic changes induced by the three agents may, of course, be quite dissimilar. 

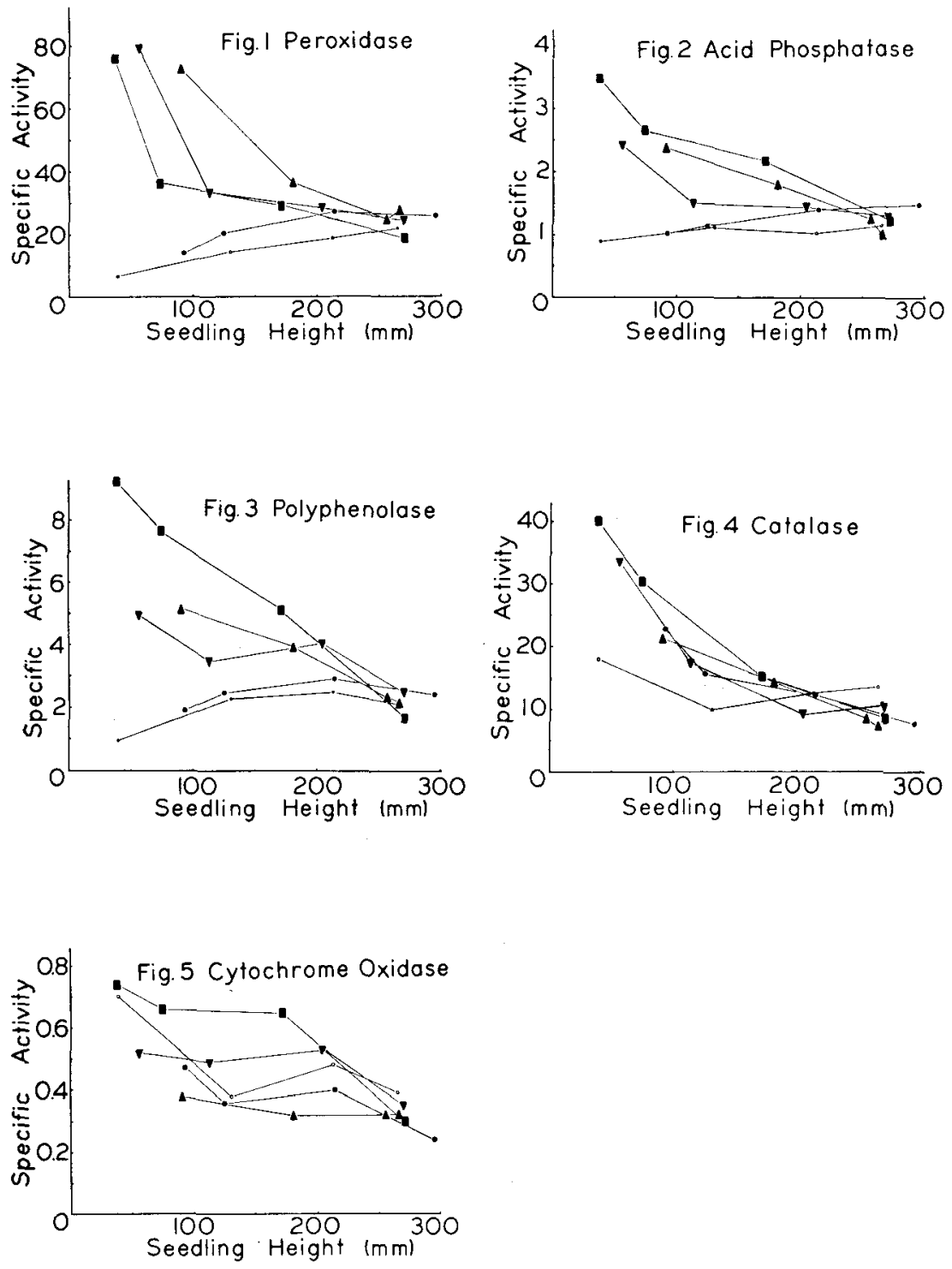

Figures 1-5. Relationships between seedling height and five types of enzyme activity for corn seedlings which varied in height because of the effects of age $0-0$, temperature

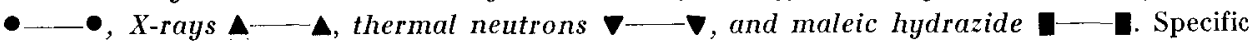
activities are expressed in the following units per minute per mg protein $\mathrm{N}$ : peroxidase - increase in optical density at $460 \mathrm{~m} \mu$; acid phosphatase - micromoles $p$-nitrophenol liberated; polyphenolase - increase in optical density at $410 \mathrm{~m} \mu$; catalase - micromoles $\mathrm{H}_{2} \mathrm{O}_{2}$ destroyed; cytochrome oxidase -- micromoles cytochrome $c$ oxidized. 
Mackey (1951) and Caldecott, Frolik, and Morris (1952) have reported that in barley grown from X-ray- and neutron-treated seeds, the frequency of chromosomal abnormalities in relation to reductions in plant height or survival is distinctly less for X-ray treatments than for neutron treatments. On the basis of this observation they have suggested that $\mathrm{X}$-rays bring about pronounced physiological or extra-chromosomal effects which are not found following neutron irradiation. Beard (1955) has reported similar data for corn. Since the present experiments have not demonstrated any large differences between the two types of radiation, the suggested physiological effect is apparently not closely related to any of the enzyme activities considered here.

\section{Summary}

Corn seedlings of various heights were obtained from seeds treated with various dosages of $\mathrm{X}$-rays, thermal neutrons, or maleic hydrazide, and also from non-treated seeds by adjusting duration of the growth period or temperature during growth. These seedlings were used in making enzyme preparations, and the activities of the preparations with respect to catalase, cytochrome oxidase, peroxidase, acid phosphatase, and polyphenolase were determined. It was found that seedlings which were small as a result of seed treatment with $\mathrm{X}$-rays, thermal neutrons, or maleic hydrazide yielded enzyme preparations which were appreciably higher than controls in peroxidase, phosphatase, and polyphenolase activities, while seedlings which were small because of age or temperature effects yielded preparations which were relatively low in these three enzyme activities. Assays of catalase and cytochrome oxidase, on the other hand, disclosed that with reduced seedling height there was a tendency toward increased activity regardless of the treatment employed to effect the reduction in seedling height.

Published with the approval of the Director as Paper No. 741, Journal Series, Nebraska Agricultural Experiment Station, Lincoln, Nebraska. Research was conducted under Contract No. AT (11-1)-169, United States Atomic Energy Commission. Acknowledgment is made to Mr. Warren W. Sahs, Foundation Seed Division, University of Nebraska for supplying the L289 $\times$ I205 seed.

\section{References}

Beard, B. H.: A comparison of the effects of X-rays and thermal neutrons on the dormant seeds of barley, maize, mustard, and safflower. - Ph. D. Dissertation, University of Nebraska. 1955.

Caldecott, R. S., Frolik, E. F. \& Morris, R.: A comparison of the effects of X-rays and thermal neutrons on the dormant seeds of barley. - Proc. Nat. Acad. Sci. 38: 804. 1952. 
Haskins, F. A.: Changes in the activities of several enzymes during germination and seedling development in corn (Zea mays L.). - Plant Physiol. 30: 74. 1955.

Hoagland, D. R. \& Arnon, D. I.: The water-culture method for growing plants without soil. - California Agricultural Experiment Station Circular 347 Revised. 1950.

Mackey, J.: Neutron and X-ray experiments in barley. - Hereditas 37:421. 1951.

Mikaelsen, K. \& Halvorsen, H.: Experiments on the respiration of X-irradiated barley seeds. - Physiol. Plant. 6: 873. 1953.

Patt, H. M.: Radiation effects on mammalian systems. - Ann. Rev. Physiol. 16:51. 1954.

Powell, W. F. \& Pollard, E.: Radiation inactivation of enzymes inside and outside intact cells. - Radiation Research 2: 109. 1955.

Schmidt, J. W. \& Frolik, E. F.: The effects of thermal-neutron irradiation of maize and barley kernels. - University of Nebraska Research Bulletin 167. 1951. 